\title{
Correction to: Poverty dynamics and graduation from conditional cash transfers: a transition model for Mexico's Progresa-Oportunidades-Prospera program
}

\author{
Juan M. Villa ${ }^{1} \cdot$ Miguel Niño-Zarazúa ${ }^{2}$
}

Published online: 9 November 2018

(C) UNU-WIDER 2018

\section{Correction to: J Econ Inequal \\ https://doi.org/10.1007/s10888-018-9399-5}

The original version of this paper contained a copyright line @The Authors. This should have been OUNU-WIDER 2018.

The original article has been corrected.

The online version of the original article can be found at https://doi.org/10.1007/s10888-018-9399-5.

Juan M. Villa

Juan.villa@manchester.ac.uk

Miguel Niño-Zarazúa

miguel@wider.unu.edu

1 Global Development Institute, University of Manchester, Arthur Lewis Building, Oxford Road, Manchester, M13 9PL, UK

2 United Nations University World Institute for Development Economics Research (UNU-WIDER), Katajanokanlaituri 6 B, FI-00160 Helsinki, Finland 